
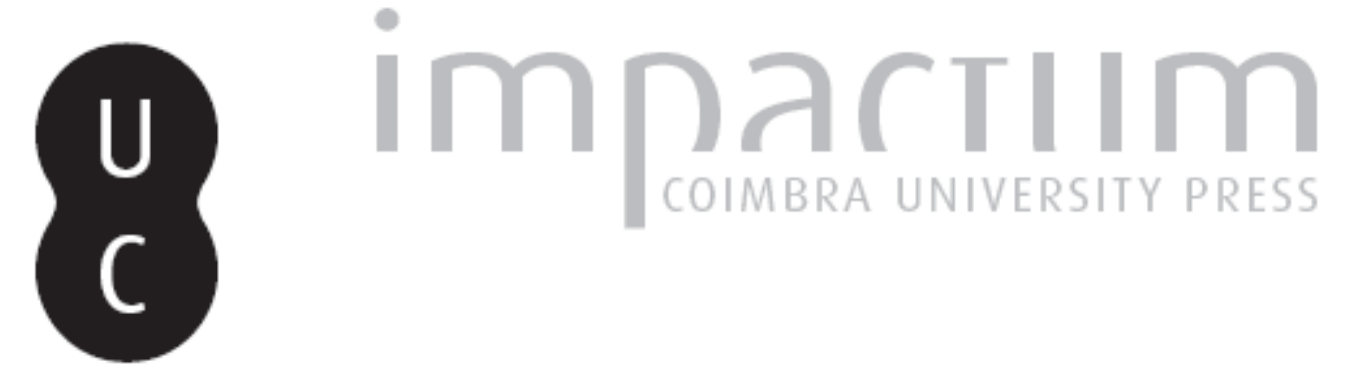

\title{
[Recensão a] MARTINS, Leonor Pires - Um império de papel: imagens do colonialismo português na imprensa periódica ilustrada (1875-1940)
}
Autor(es):
Neto, Sérgio

Publicado por: Imprensa da Universidade de Coimbra

URL persistente:

URI:http://hdl.handle.net/10316.2/36820

DOI:

DOI:http://dx.doi.org/10.14195/1647-8622_13_27

Accessed : $\quad$ 26-Apr-2023 13:52:11

A navegação consulta e descarregamento dos títulos inseridos nas Bibliotecas Digitais UC Digitalis, UC Pombalina e UC Impactum, pressupõem a aceitação plena e sem reservas dos Termos e Condições de Uso destas Bibliotecas Digitais, disponíveis em https://digitalis.uc.pt/pt-pt/termos.

Conforme exposto nos referidos Termos e Condições de Uso, o descarregamento de títulos de acesso restrito requer uma licença válida de autorização devendo o utilizador aceder ao(s) documento(s) a partir de um endereço de IP da instituição detentora da supramencionada licença.

Ao utilizador é apenas permitido o descarregamento para uso pessoal, pelo que o emprego do(s) título(s) descarregado(s) para outro fim, designadamente comercial, carece de autorização do respetivo autor ou editor da obra.

Na medida em que todas as obras da UC Digitalis se encontram protegidas pelo Código do Direito de Autor e Direitos Conexos e demais legislação aplicável, toda a cópia, parcial ou total, deste documento, nos casos em que é legalmente admitida, deverá conter ou fazer-se acompanhar por este aviso.

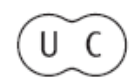




\section{estado-providência}

ESTUD OSD OSÉCULO

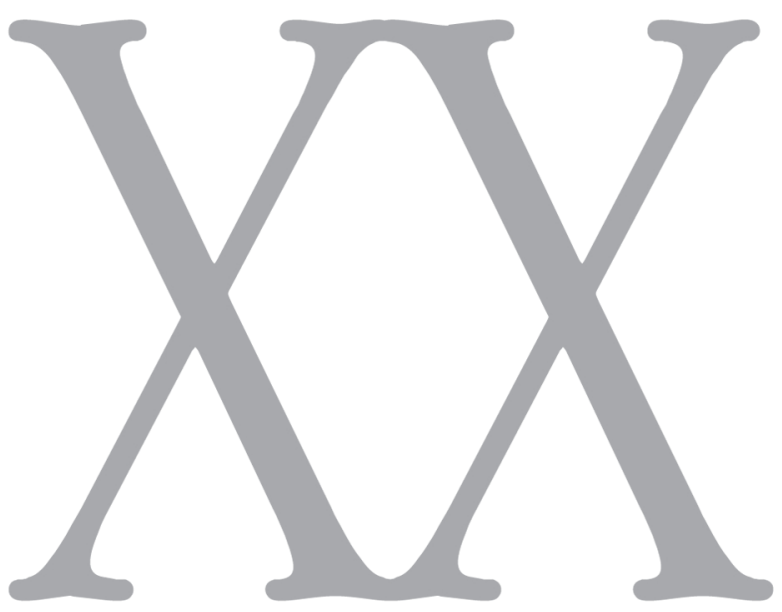

número 13 • 2013

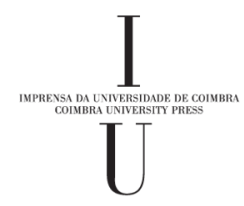


MARTINS, Leonor Pires - Um império de papel: imagens do colonialismo português na imprensa periódica ilustrada (18751940). Lisboa: Ediçóes 70, 2012. 214 p.

Dotado de um sugestivo título, capaz de enfatizar a desmesurada dimensão propagandística que o império colonial português espelhou nos finais do século XIX e ao longo de boa parte do século XX, o livro da antropóloga Leonor Pires Martins, pela profusão das imagens e pela cronologia alargada, sem esquecer a originalidade da temática, possui uma qualidade não apenas gráfica, mas, sobretudo, constitui introdução a uma problemática poucas vezes abordada. Com efeito, entendendo que "as representaçóes visuais do império carecem de um recenseamento sistemático" (p. 11), a autora abalança-se a uma recolha e consequente análise crítica dos periódicos de vocação colonial e daqueloutros que fizeram da imagética ultramarina um campo de acção secundária. Deste modo, através de uma criteriosa divisão dos momentos mais marcantes da contemporaneidade colonial portuguesa, numerosas imagens de jornais e revistas referentes à vida de além-mar surgem enquadradas por texto explicativo, ao passo que, noutras ocasióes, é a prosa que suscita a ilustração. No que se refere à cronologia, esta busca delimitar um período mediado entre a criaçáo da Sociedade de Geografia de Lisboa e a Exposição do Duplo Centenário (do Mundo Português), momentos de consciencialização do império e de afirmação política.

Dividido em cinco capítulos e um posfácio da especialista em estudos pós-coloniais Manuela Ribeiro Sanches, a obra compreende 214 páginas. A primeira parte, intitulada "Imaginar o Império - o Papel da Imprensa Periódica", faz as vezes de introdução, concluindo que "à luz da ideologia dominante, poder-se-á dizer que [...] o 'Império Colonial Português' foi pensado como uma comunidade imaginada” (p. 24). Citando, assim, o famoso livro de Benedict Anderson, Leonor Martins explica a distância que vai do império sonhado - que remontaria aos Descobrimentos - ao império real, o Terceiro Império Português ou último ciclo imperial, o qual foi (re)criado após a independência do Brasil e a acalmia na situação política metropolitana trazida pela Regeneração. Também, a este propósito, náo perde de vista a quase ausência de uma verdadeira arte e literatura de raiz colonial, pelo que a imagética ultramarina ter-se-ia em muito restringido às publicaçóes periódicas e às exposiçôes.

Por seu lado, a segunda parte, "Viragem à África e Corrida às Imagens", cindida em "A Iconografia das Expediçôes", "Contratempos" e "Um Novo Fôlego Imperialista”, debruça-se sobre a importância da Sociedade de Geografia de Lisboa, fundada em 1875, na exploração do então desconhecido continente africano. Apresentando imagens das revistas O Ocidente. Revista Ilustrada de Portugal e do Estrangeiro (1878-1915) e As Colónias Portuguesas. Revista Ilustrada (1883-1892), a tónica é posta nas expedições ao hinterland, como as levadas a cabo por Serpa Pinto e Capelo e Ivens. Enquanto a revista Pontos nos ii (1885-1891) dava conta dos sobressaltos patrióticos sucedendo o Ultimato Inglês de 1890, O Ocidente registava os êxitos das "campanhas de pacificação" conduzidas pela "geração de Mouzinho de Albuquerque".

Se, na terceira parte, o fotógrafo J. A. da Cunha Moraes, o "caçador de imagens da África Ocidental”, é o protagonista, na quarta, "Zoom à África Branca”, o palco é ocupado por novos e velhos colonos, por governadores, como Norton de Matos, e pelo quotidiano da vida "num lugar ao 
sol”. Os periódicos mais focados são, agora, Ilustração Portuguesa (1903-1923), Ilustração (1926-1937) e O Mundo Português (1934-1947), o qual foi editado, com bastante êxito, pela Agência-Geral das Colónias e pelo Secretariado da Propaganda Nacional, durante a fase da "Mística Imperial" do Estado Novo.

Por sua vez, na quinta parte, "No Papel e ao Vivo", são passadas em revista algumas exposiçóes, através das quais os diferentes regimes políticos buscaram auto-representar-se, exibindo salas, objectos, mostras e pessoas, enquanto microcosmos de um "vasto império" e espelho de uma supostamente singular vocação colonial, que nos apartaria das demais naçóes europeias. Como seria de esperar, a Exposição Colonial do Porto (1934) e a Exposição do Duplo Centenário (1940) são as mais visadas. No entanto, a autora, talvez por maior conhecimento geral deste último acontecimento, explora, mais demoradamente, a exposição do Porto, embora sem recorrer à revista Ultramar. Órgáo Oficial da Exposiçâo Colonial do Porto (1934).

De resto, esta constitui uma crítica a um trabalho, em todo o caso, bem gizado: a predominância de certas revistas, como O Ocidente, cujas fotografias e ilustraçóes ocupam a maior parte do volume, e a consequente marginalização de Jornal da Europa (1927-1931), do Álbum das Colónias Portuguesas (1933) do referido Ultramar, da Revista dos Centenários (1939-1940), de Humanidade (1935-1939) - todas portadoras de imagens apelativas que, em boa verdade, pela sua novidade editorial, marcariam a transição da Primeira República para o Estado Novo, através de um recrudescimento da propaganda colonial.

Sérgio Neto

Investigador Colaborador do CEIS20
PEREIRA, Bernardo Futscher A Diplomacia de Salazar (1932-1949). 2. ' Edição. Alfragide: Dom Quixote, 2013. 591p, ISBN 978-972-20-5181-1.

Em Fevereiro de 2013 foi lançada, pelas Publicaçôes Dom Quixote, a segunda edição do livro A Diplomacia de Salazar (1932-1949). Da autoria de Bernardo Futscher Pereira, actual embaixador de Portugal em Dublin, e ex-assessor para as Relaçóes Internacionais do Presidente da República, Jorge Sampaio, a obra de 591 páginas divide-se em seis partes. Se, a primeira, balizada por Julho de 1932 e Julho de 1936, segue de perto a chegada ao poder de Salazar e a crise da Abissínia (1935-1936), a segunda acompanha a eclosão da Guerra Civil de Espanha, observando este conflito, que terminou em Abril de 1939, com a vitória do Generalíssimo e as suas repercussões no Terreiro do Paço.

A terceira parte que, cronologicamente se estende de 1939 a 1941 , ou seja, do começo da Segunda Guerra Mundial à invasão da União Soviética pelas tropas alemãs, retrata as tensões acumuladas antes do conflito e a ameaça que pairou sobre a soberania e a integridade territorial de Portugal nos primeiros anos da contenda. A quarta, de 1941 a 1943, analisa a cedência de utilização aos Ingleses, por parte do governo de Lisboa, da base das Lajes nos Açores, que se constituiu como importante ponto de apoio para as missóes no Oceano Atlântico e no teatro de operaçóes europeu.

A quinta parte, que se estende de Outubro de 1943 até ao verão de 1945, para além de abordar uma série de mudanças "cosméticas" feitas pelo regime, decorrentes da vitória das democracias e da posição hegemónica dos Estados Unidos, refere ainda o processo de recuperação de Timor, que, depois de ter sido invadido pelos aliados neerlandeses e australianos, havia sido ocupado pelos 